\title{
Historical Institutionalism and Foreign Policy Analysis: The Origins of the National Security Council Revisited
}

This is a post-peer-review, pre-copyedit version of an article published in Foreign Policy Analysis. The definitive publisher-authenticated version 'Historical Institutionalism and Foreign Policy Analysis: The Origins of the National Security Council Revisited', Foreign Policy Analysis Vol. 7, No. 1: pp. 27-44, is available online at:

http://onlinelibrary.wiley.com/doi/10.1111/j.1743-8594.2010.00121.x/full

Bryan Mabee

School of Politics and International Relations

Queen Mary, University of London

Mile End Road

London E1 4NS

UK

\section{Abstract:}

The article develops the insights of historical institutionalism and cognate work within International Relations to examine the development of security institutions within states, dealing specifically with the development of the National Security Council (NSC) in the United States. The case focuses on the creation and reproduction of the NSC as a means to fostering civil-military coordination within the US state. The article argues that exogenous shocks are crucial in providing the necessary freedom to change existing institutions, which are then set on new contingent paths. Substantively it is argued that World War II and the experiences derived from it provided a critical juncture for the creation of new security institutions such as the NSC, and once created the NSC was characterized by forms of path dependence that have reproduced the institution over time. The article demonstrates how historical institutionalism can clarify causal mechanisms that better explain the origins and durability of internationally-oriented security institutions within states.

On July 26, 1947, President Truman signed the National Security Act, ending years of debate about the unification of the US armed forces. The Act inaugurated not only an unheralded change in the bureaucracy of the federal government, but also formally institutionalized a new set of relationships regarding civil-military coordination, mainly seen in the creation of the National Security Council (NSC), and (in 1949) the Department of Defense, that are key parts of what can be called the "national security state" (Yergin 1977; Hogan 1998; Stuart 2008a). On the face of it, explaining such a change should be straightforward in terms of conventional approaches in International Relations (IR) and its subfield of Foreign Policy Analysis (FPA): such a change was necessary to better provide for the national security, and represented at best a rational (instrumental) solution to a present problem, or at worst a political compromise to deal with a clash of interested parties. However, such explanations 
seem to leave much out of the story. Why 1947 ? After years of failed attempts to do anything about coordination, why was the postwar moment so ripe for change? How was traditional anti-statism in the US overcome? Additionally, what are the enduring consequences of such institutions? Such questions are not just interesting in terms of the case at hand, but also for trying to identify the kinds of causal mechanisms that allow institutional change and reproduction in the postwar case.

The analysis of institutions in IR has had a long pedigree, from the study of formal international organizations to the more recent work on international regimes (Krasner 1981; Kratochwil and Ruggie 1986). Much of the work on such institutions has been in the form of either rational choice institutionalism - a focus on institutions as instrumental results of agential preference - or in the form of more constructivist-oriented work that sees institutions as shared set of identities (or rules) that govern social relations (Fearon and Wendt 2001; c.f. Wendt 2001). These two approaches tend to focus on very different aspects of institutions: choice theoretic approaches focusing on the results of processes of institutionalization, constructivists on the development of ideas fostering such institutions (Glenn 2003). As such both tend to be more interested in the outputs of institutions rather than their origins or development in time. Work by those using historical institutionalist forms of analysis has been much less prevalent in IR, though effectively utilized by a number of scholars in a variety of contexts (e.g. Krasner 1984; Spruyt 1994; Ikenberry 2001; Nexon 2009). All of these authors have recognized both the historical contingency and path dependency of the development of institutions, in ways that are often overlooked by the two dominant forms of analysis.

The recognition of a historical institutionalist alternative serves a different function in the present article. While many institutionally-minded IR scholars look at international institutions, the development of institutions that mediate foreign policy within the state have been much less commented upon using such theoretical approaches. Though a rich literature has developed analyzing foreign policy-making in terms of the psychology of decisionmaking, and through the development of organizational cultures that impact on decisionmaking, much of this literature is limited in its engagement with historical institutionalism as 
a mode of analysis. ${ }^{1}$ The main problem with the FPA literature on these grounds is that it, like the institutional analyses mentioned above, is more interested in foreign policy outputs than institutional design or historical development. The historical institutionalist approach could have much to say in terms of two factors: the importance of critical junctures in creating initial institutional pathways; and how positive feedback creates causal mechanisms that inhibit change in institutions over time. Some of the latter claims are implicit in the literature, but they make little sense without a proper discussion of critical junctures (Pierson 2004).

Zegart (1999) has put forward one prominent attempt to explain the creation and evolution of security institutions within the US through a "new institutionalist" understanding. While her account moves the debate substantially forward, it does not go far enough in addressing some of the issues brought up by the historical institutionalist project. ${ }^{2}$ In the following, a complementary account to Zegart's analysis is provided by examining the development of the National Security Council (NSC) through a broadly historical institutionalist analysis. The article first focuses on how institutional change can be analyzed in the context of security institutions, to better understand the origins and pathways of institutions in foreign policy making. A cue is taken from Pierson's (2004) work on path dependency and positive feedback in order to develop a historical method for analyzing institutional design and development. The analytic framework for examining path dependent institutions and processes is then utilized to examine the development of the NSC in more detail, in order to explain what has become a familiar story in a different manner.

The article puts forward two core claims concerning the development of the NSC after World War II. First, the importance of timing in institutional development is examined: the NSC (as part of the National Security Act) could only have been created when it was due to a variety of contingencies. The explanation of why reforms were made at this particular time is best explained by a critical juncture of a number of events - the endogenous desire for reform plus the (exogenous) insecurity created by the Japanese attack on Pearl Harbor and the

\footnotetext{
${ }^{1}$ For example, see the overviews in Carlsnaes (2002) and Hudson (2005).

${ }^{2}$ Granted that Zegart may not have been interested in some of these questions: her account is mainly geared at explaining why security agencies are not rationally (or functionally) designed.
} 
experience of World War II (reinforced by an increasing Soviet threat). This claim draws on Zegart's focus on the sub-rationality in the development of institutions, but puts history and timing back into the account. Second, the mechanisms of evolution and the reproduction of the NSC are accounted for. The second claim concerns the durability of institutions. Once the NSC was institutionalized, positive feedback mechanisms enabled its longevity, especially through the combination of increased presidential power over foreign policy and the increased actual use of the NSC as a coordinating body. This claim points to the importance of specific casual mechanisms and social relations reproducing security institutions over time.

Overall, the article uses the creation of the NSC as a means to seeking better explanations of important socio-political phenomena through the utilization of a more historically-nuanced approach to explaining institutions. The substantive claims about the creation and reproduction of the NSC will be placed in the context of the usefulness of historical institutionalism for understanding international relations.

\section{Explaining Institutional Change in Foreign Policy and Security Institutions}

The development of the NSC after World War II has been surprisingly under-studied within the field of IR. While a number of historians have looked at the development of the NSC in the context of the National Security Act and state-building postwar, it has received relatively little attention in IR or FPA. ${ }^{3}$ Zegart's (1999) account of the development of the NSC, Joint Chiefs of Staff and CIA is one of the few sustained analyses in the IR literature that amounts to an actual theory of institutional creation of national security institutions (or "agencies" as she refers to them). Indeed her work provides a sophisticated economic "new

\footnotetext{
${ }^{3}$ Within IR three books stand out: Zegart (1999); Friedberg (2000); and Stuart (2008a), which has more recently analysed the 1947 Act in the context of the aftermath of World War II (Stuart's account overlaps somewhat with my own, though it does not explicitly draw on historical institutionalism as an approach). Rothkopf (2005) and Prados (1991) give historical overviews that are not focused on explaining institutions. Daalder and Destler (2009) focus on individuals (primarily from 1960 onwards), and give a rich account of the policy process and the interactions between presidents and particular national security advisors. Older evaluations can be found in May (1955), Hammond (1977), Neu (1987) and Falk (2004). Additionally, there have been a number of works on the postwar era in American political development that focus more broadly on the "national security state", which have drawn on historical institutionalism, implicitly or explicitly: e.g. Sherry (1995); Hogan (1998); Grossman (2001); and Waddell (2001).
} 
institutionalist" analysis of the development of foreign policy institutions, and has the virtue, as explicitly stated in her study, of taking such agencies seriously as objects of analysis in their own right. As she points out, such organizations tend to be "too domestic" for most IR scholars, and "too international” for specialists in American politics (Zegart 1999: 3).

Zegart's main argument is that the form of those institutions of national security was greatly impacted upon by institutional bargaining: i.e. the form was not rational or efficient. Drawing on the new institutionalism in political science, Zegart sets up a modified account of the creation of governmental agencies, which points to the clash of interests that go into the process of agency creation. In the "domestic" account, Congress leads agency design, with the actual design being suboptimal due to bargaining between Congress (Congressional champions) and interest groups. The evolution of such agencies is explained mainly through Congress: its initiatives, oversight and legislation, and finally through the changing environment of Congressional committees, interest groups, etc. In Zegart's modified account, the Executive branch drives agency design, and the conflict of interest comes from competing bureaucratic interests within the Executive branch. The Executive branch also drives evolution, due to low Congressional oversight, and other sources of change tend to include initial agency structure, interests, and environment (Zegart 1999).

Zegart's account certainly hits its intended target: rational actor accounts of international relations, as well as the limits of FPA. In terms of the former, she is keen to point out the importance of sub-optimally designed agencies, as the logic of rationalist approaches to IR sees the structure of government as being able to pursue whatever foreign policy is most rational (i.e. policies which promote the continued well-being of the state), and as such, internal agencies should be designed with this in mind. That agencies are political products created non-functionally and may lead to poorly formulated and implemented foreign policy is a real knock to the elegant rationalist theory of international relations. Zegart is also targeting FPA scholars who take little interest in such agencies as dependent variables: as she argues FPA scholars are primarily interested in the outputs of such agencies, and do not see

\footnotetext{
${ }^{4}$ There is a key distinction between the economic and sociological versions of the "new institutionalism". For a sustained discussion, see Taylor and Hall (1997) and Immergut (1998); for some representative examples, see March and Olsen (1984) and Moe (1984).
} 
them as important objects of analysis in their own right. ${ }^{5}$ As an overall critique of the rational actor assumption, and of opening up a neglected area of discussion within FPA, Zegart is successful.

While Zegart's analysis is convincing in regards to the politics of agency creation (and in much of the account of the problems that initial developments create for the future), it seems less well-suited for accounting for why the change happened at that particular time. In fact, her new institutionalist theory of foreign policy actors within states deliberately discounts exogenous events (be they changes in international relations or other environmental factors) in the process of institutional creation, in favor of a focus on domestic politics, and particularly the clash of interests inherent in institutional creation. This serves an important purpose for her theory: to show that domestic politics is more important than international politics in the institutional creation of domestic security institutions. International events may set the context, but actual agency design is done through domestic bargaining: "international factors may have prompted the unification issue to arise, but only domestic political wrangling explains how it was settled" (Zegart 1999: 106). While ignoring international events in terms of the eventual creation of institutions seems fine inasmuch as it goes away from a rational/efficiency account of institutional development, it ignores the actual causal chains leading to institutional creation.

This can be seen in two distinct ways. First, it avoids the importance of particular critical junctures of events allowing for the possibility of institutional creation. The extent to which such critical junctures lead to institutions impacts on both the form they can take as well as having substantial downstream effects. Tilly (1995) has noted that regularities in political life do exist, but are highly contingent on their timing. That is not to say that there are not recurrences, just that, as Tilly (1995: 1601) notes, "recurrent causes which in different circumstances and sequences compound into highly variable but nonetheless explicable

\footnotetext{
${ }^{5}$ Compare the classic work of Allison and Zelikow (1999) with the overviews of Carlsnaes (2002), Hill (2003) and Hudson (2005). See also the forum on the state of FPA in the journal International Studies Review (Garrison 2003).
} 
effects". ${ }^{6}$ For example, Zegart's account purports to establish a theory of security agency development, focusing on the role of Executive branch versus Congress, interest group behavior, and the insularity of such agencies. However, much of the impetus for institutional creation in these cases is highly contingent on historical circumstances, and any theory of the development of such agencies needs to take these contingent circumstances - their historical causes - into account if they are to be understood. In the case at hand, previous attempts to unify the armed forces were not able to succeed due to timing: as such the postwar (and postPearl Harbor) environment is crucial to institutional creation, and for explaining the origins of the NSC.

Second, critical junctures also delimit the potential options for institutional creation: it is not just the embedded interests of the players involved in institutional creation that leads to sub-rationality, but the timing of creation. Again, the development of greater civil-military cooperation and centralization was not just due to interagency bargaining, but due to the experiences of World War II. Overall, it is a mistake to treat international politics as a source of institutions in the sense that international events impel actors to create institutions in order to rationally deal with some threat, rather than as creating a critical juncture for the possibility of institutional creation. That in this particular instance such events are exogenous to the political system may be unique, but perhaps not so unique for the creation of internationallyoriented domestic agencies.

These issues all pose problems for the new institutionalism. Showing the political conflict in decision-making has the virtue of moving the analysis away from functionalism, as well as the addition of a focus on agency creation, but is less clear on a number of other issues, including the historical causation of the particular case, and also about the particular mechanisms of institutional evolution and reproduction. And here the difference becomes clear between the purpose and methods of a choice-theoretic institutionalism and historical institutionalism. As Thelen (1999: 382) argues, "whereas rational choice theorists tend to view institutions in terms of their coordinating functions, historical institutionalists see

\footnotetext{
${ }^{6}$ This chimes with Abbott's (2001: 256) description of “peculiarly essential junctures as being like arrangements of tumblers in a lock: if an action sits just right under the tumblers, it becomes the key that opens, the agent of sudden advantage or disadvantage".
} 
institutions as the legacy of concrete historical processes". Though many of the distinctions between these two approaches to institutions are becoming blurred, the focus on historical causation and path dependent processes (as well as institutional evolution) is a real hallmark of the historical institutional approach. ${ }^{7}$ These two types of causal analysis become of paramount importance: and in analyzing the creation and reproduction of security institutions in the US post-World War II, historical causation is rather underspecified in Zegart's model, stressing as it does the politics of institutional creation rather than the specific historical conditions that give rise to the possibility of institutional creation.

For historical institutionalists, the influence of particular historical junctures for institutional creation is of crucial importance to institutional creation (Mahoney 2000; Pierson 2004; c.f. Mahoney and Rueschemeyer 2003; and Capoccia and Kelemen 2007). ${ }^{8}$ Critical junctures, "moments when substantial institutional change takes place thereby creating a 'branching point' from which historical development moves onto a new path" (Hall and Taylor 1996: 942), need to be specified in order to see how monumental change can happen in the first place, as these junctures are as crucial to institutional creation as the specific bargaining between actors that provides the act of creation. The reasons for this are twofold. First, critical junctures tend to provide exogenous pressures on political orders that need to be dealt with for political orders to continue (Lieberman 2002; c.f. Hay 1999). Second, institutional creation, development and reproduction are so highly contingent on such junctures that the causal pathways for creation need to be properly mapped out in order to understand why particular institutions are created, how they are reproduced, and how they can evolve.

Having given a brief overview of the importance of historical institutional analysis in terms of explaining critical junctures, it remains to utilize the concept in examining the development of the NSC in the US post-World War II. While much of the criticism above

\footnotetext{
${ }^{7}$ Thelen (1999) goes through a number of the blurred areas (while maintaining that some distinctions such as theoretical versus empirical work; endogenous versus exogenous preferences; micro versus macro research; functional versus historical institutions - still remain important), while Pierson (2004) provides a synthesis of sorts between the two positions.

8 There are important similarities between the historical institutional literatures and social theoretic approaches that attempt to put time back in social analysis in a meaningful manner; e.g. Abbott (2001) and Sewell (2005).
} 
was focused on rational choice institutionalism, this is not because it is seen as wrong; rather it is partial in its explanations. Zegart's work was highlighted due to its focus on the institutions in question, and particularly in exemplifying the strengths and weaknesses of the new institutionalism.

\section{A Critical Juncture: World War II and the Creation of the National Security Council}

The historical institutionalist approach stresses the role of critical junctures in leading to institutional change (Hall and Taylor 1996; Mahoney 2000; Pierson 2004). Focusing on such junctures can better explain why events can cause certain impacts only at particular times, when a variety of variables line up in productive manner. The legacy of such junctures is important in a number of ways, but mainly due to the contingency of outcomes, and to the downstream effects of such moments. Overall, the development of robust security institutions within the US after World War II, through unification of the armed forces, greater civilmilitary integration, and the creation of intelligence agencies need to be seen as part of a broader context of historical explanation. To borrow a phrase from Pierson (2000; c.f. 2004), it is "not just what, but when" that is important in institutional creation.

The move towards the National Security Act and unification was a compromise of sorts between the key bureaucratic players (the Departments of War and Navy) and the president. ${ }^{9}$ The Department of the Navy had long been opposed to unification, as it was seen as a threat to the autonomy of the Navy in terms of its organization, its direct access to the president, and budget appropriations; and also through its fear of decline relative to the Army and Air Force. The Army, however, with much to gain, was pushing for much more centralization: a permanent Secretary of Defense, with control of access to the president, and control over budgets. Because of the Army's wartime experiences, it seemed centralization was the best way to promote the Army against the other services; centralization was also seen as more efficient, as part of Army traditions. The pushing and pulling that resulted in the full NSC system and the creation of the National Military Establishment ended up being a compromise

\footnotetext{
${ }^{9}$ The account of the next few paragraphs is drawn from: Caraley (1966); Hammond (1977); Nelson (1981); Hogan (1998); and Zegart (1999).
} 
of both of these things: the NSC became an advisory body that lacked authoritative power, and the Secretary of Defense had less power than was hoped for (Truman 1956: chap. 3).

In the instance of the NSC, a plausible question can be asked about why it was created when it was, and more specifically why was its "Magna Charta" (as Hogan (1998) describes it), the National Security Act of 1947, was passed when it was. Though this may sound a rather banal question, it seems important in looking back to the sequence of events that led to the passing of the Act, and why the issues that it dealt with were of such importance. If the outcomes of the Act were rather sub-optimal, as Zegart has argued, then we still might ask the question of why the institutions were even possible to create at the time.

An important starting point can be seen focusing specifically on the dual issues of the civilian coordination of the armed services and greater political-military consultation; we can legitimately ask why such reform had not been successful earlier, and what specifically about the postwar moment made reform a possibility (or even a necessity). Unification had been an issue from the late-nineteenth century onward, often, unsurprisingly, as the consequence of major wars. ${ }^{10}$ Borklund (1966) notes a number of early proposals for unification of Army and War with a variety of relationships, and also the narrow defeat in the House in 1932 of a fullblown institution similar to the Department of Defense (though proposed entirely as a costcutting measure). Although it was the unification of the armed forces was where the main battlelines of the post-World War II debate were drawn, the creation of the NSC was an important part of the proposals, if often forgotten about in the heated battles between the Army and Navy and the president in the debates surrounding unification. ${ }^{11}$

The problem of coordinating a long-term strategy for foreign policy had been realized by a few, as May (1995) points out, ${ }^{12}$ at the beginning of the twentieth century. Many of these commentators recognized the poor planning and coordination between the Navy and War

\footnotetext{
${ }^{10}$ There is a broad literature demonstrating the relationship between war and political change, especially in terms of the expansion of state capacity after wars: e.g. Skowronek (1982), Bensel (1990), Porter (1994), Sherry (1997), Hogan (1998) and Mayhew (2005).

${ }^{11}$ Details can be found in Caraley (1966); Hammond (1977); Hogan (1998: esp. chap. 2); Zegart (1999); and Stuart (2008a: esp. chaps. 3 and 4). Forrestal had made the NSC an integral part of Navy's position, as seen in the Eberstadt report, even if it was subordinate to the greater issue of Navy autonomy (Caraley, 1966; Hogan, 1998).

${ }^{12}$ The following paragraph draws heavily on May (1955).
} 
departments, and the Department of State. Across the late-nineteenth to early-twentieth century, consultation between State, War and Navy was done through personal communication between the three Secretaries. Though obviously a form of consultation, it never worked effectively, and military and political decisions often reached the White House separately, and the president ended up having to weigh the differences between political and military objectives, in order to form some sort of coherence. Though experiences in World War I and reforms to all three executive departments increased some desire for consultation, much proposed went nowhere. ${ }^{13}$ May's account (though possibly a bit too deterministic in charting the legacy) shows the evolution towards an increased political-military consultation, which should be seen as a form of civil-military relations, had been around for some time, but never made possible (c.f. Stuart 2008a: esp. chap. 1).

Talk of clearer military-political collaboration long preceded World War II, as May (1955) has ably demonstrated, so why was institutional creation not possible in the interwar period? In many ways the answer is obvious, as the problems with inter-service communication were seen as leading to the Pearl Harbor attack, and the realties of total war required a more unified approach to national defence. However, as the institutions that were created out of the Act were not as efficiently designed as hindsight (or functionalism) might perceive, it is of necessity to better specify why 1947? The obvious answer to why they had never been achieved was due to the lack of overall urgency: as the system of foreign policy coordination that existed at the time had not led to any disasters, or been impacted upon substantially by external events, there was no need for change. As May (1955: 162) points out, "long years of isolated safety smothered the idea of political-military collaboration". So, the main intervening causal factor, unsurprisingly, was the exogenous event of global war.

However, an easy retrospective narrative should not belie the difficulty in seeing how the "lessons" of war could have led to a number of different institutional outcomes: a more centralized and militarized state, a more New Deal-style domestic focus, an international strategy based on diplomacy and economics, or an isolationist foreign policy (with an anti-

\footnotetext{
${ }^{13}$ May (1955) notes that a 1919 letter sent by then Secretary of the Navy Franklin D. Roosevelt outlining a joint organization for war planning, containing representatives from all three departments, had not been acknowledged, delivered to the wrong address, and for all intents and purposes, unopened.
} 
statist impulse) (May 1992: 219). However, the critical conjuncture of events, ideas and friction of previous institutions combined in this particular critical juncture to lead to a stronger state, but one that was more based on civilian coordination than military leadership. In addition to the already mentioned issue concerning overcoming inter-service rivalries and communications concerns in the aftermath of Pearl Harbor, ${ }^{14}$ four factors here seem especially important.

First, the attack at Pearl Harbor and the nature of total war led to an increased sense of insecurity, leading to a need for permanent preparedness. As John Lewis Gaddis (1987: 2122) notes, "this [new] sense of vulnerability is basic to an understanding of how Americans perceived their interests - and potential threats to them-in the postwar world". Prior to the sense of vulnerability created by the Pearl Harbor attack, the US had sought security through the protection of the Americas from external influences, a legacy of the "isolationism" of earlier leaders, but also borne of experiences from the interwar period: the inward looking nature of economic development and of economic recovery (Gaddis 1987: 22). Stuart goes as far as referring to the institutions created by the National Security Act as the "Pearl Harbor system" (Stuart 2008a), pointing to Pearl Harbor as the key "trigger event" (Stuart 2008b) that allowed for a redefinition of American national security (c.f. Gaddis 2004: chap. 3).

Furthermore, the signing of the National Security Act did not only draw on a new understanding of America's role in the world drawn from the experiences of World War II. The debates about unification were also made in a context where suspicion of the Soviet Union became more and more pronounced. The passage of the National Security Act also has to be seen in the context of anti-communism, that also appeared in a series of important statements on the nature of the Soviet Union, especially seen in George Kennan's Long Telegram and " $\mathrm{X}$ " article, and in Truman's articulation of the Truman Doctrine (Kennan 1947; Truman 1947; Gaddis 1987; Heale 1990; Hogan 1998). If the new security arrangements were derived from the experience of Pearl Harbor, the materialization of the Soviet Union as a threat kept the memory alive, and the necessity for preparedness (Gaddis 1987). All in all, the changes combined to make a favorable environment for the national

\footnotetext{
${ }^{14}$ For more on this aspect, see Wohlstetter (1962) and Prange (1991).
} 
security state, with all of the potential danger of militarization that its critics had warned of (Lasswell 1941). As Yergin (1977: 201) elaborates, "the doctrine of national security did not emerge apart from Soviet-American relations. It also helped to provide a framework for evaluating the problems of international politics and Soviet behaviour".

Second, a related lesson was found in the changed nature of war. In total war, the lines between peacetime and wartime were seen as completely blurred, which necessitated a permanent preparedness (Shaw 1988). America would be permanently vulnerable, because, as General Henry H. Arnold reported, nuclear weapons could, "without warning, pass over all formerly visualized barriers or 'lines of defense' and ... deliver devastating blows at our population centers and our industrial, economic or governmental heart" (Leffler 1984; Gaddis 1987: 24; cf. Stuart 2008a: chap. 1). The blurring of war and peace led to an increased perception that the state would take an increased role in organizing for security: this, as Sherry (1997: 138) notes, "embodied the conviction that in an age of instant and total warfare, the vigilant nation must be constantly prepared by harnessing all its resources and linking its civilian and military institutions - indeed, obliterating the boundary between those institutions, just as the line between war and peace was disappearing”.

Third, the existence of a new vision for security, which Hogan describes as the "national security ideology", was crucial in challenging an older discourse of the role of the state in American life. There was a clash between the new globalist national security ideology and older political traditions. One side was composed of a conservative anti-statism, which was in security terms against "entangling alliances, a large peacetime military establishment, and the centralization of authority in national government" (Hogan 1998: 8). There was an especially strong concern about increased militarism: Senator Edward Robertson, who strongly opposed unification, argued that 'the bill fostered 'militarism' and set up in the Joint Staff the 'germ' from which the 'great National General staff is expected to emerge in time' " (Caraley 1966: 169). Such a position was well-represented by the traditional anti-statism of Senator Robert Taft (Matthews 1982). The other side was made up of those agreeing with a special narrative of the US, but one that was tempered towards the needs of security in a new international environment. The debate on the bill in Congress often hinged on these arguments for the 
broader notion of security. As Hogan (1998: 60) points out, “'Remember Pearl Harbor!' was a favorite refrain, because that disaster had underscored the need for better intelligence, for teamwork between the services, and for permanent preparedness". In the Senate, reference to Pearl Harbor was also a standard pro-unification argument, one made prominently by Senator Chan Gurney, who was in charge of the bill (Caraley 1966: 168).

Finally, the overall success of the civilian-led coordination of the war, in politicaleconomic terms, certainly meant an easing into a permanent coordinating role for the state (and indeed the national security state) was not entirely unprecedented (Sherry 1987; c.f. Friedberg 2000; Koistinen 2004; Stuart 2008a: chap. 2). In fact, the role of business elites in the war-time coordination bodies, such as the War Production Board, had a lasting effect on American government, as many of those involved went on to become major players in the national security state. As Grossman (2002) has pointed out, it is certainly problematic to point to a cabal of "bullets and bankers" as much early revisionist Cold War historiography did, but the situation postwar can by no means be detached from the wartime political economy, and indeed the New Deal itself (Brinkley 1996; Waddell 2001).

The causal chains leading from World War II to the passing of the National Security Act and creation of the NSC are more complicated than a straightforward reading suggests. Overall, the explanation of why reforms were made at this particular time is best explained by a critical juncture of a number of events - the endogenous desire for reform plus the (exogenous) insecurity created by the Japanese attack on Pearl Harbor (reinforced by the potential Soviet threat) and the variety of experiences from World War II. The very contingency of the reform initiated speaks volumes about why timing is important. Reform would have been extremely difficult without an external contingency to unsettle previous arrangements. In just looking at political-military coordination in this context, we can see that without some prior desire for this kind of reform, or for the traditions of coordination in the political economy of the US, this kind of coordinating body may have been discarded in favor of something more authoritative in policy terms, or even for something more centralizing and 
militarist. ${ }^{15}$ As Lieberman (2002: 709) notes, "so when does an idea's time come? The answer lies in the match between idea and moment. An idea's time arrives not simply because the idea is compelling on its own terms, but because opportune political circumstances favor it". All in all, civil-military reform had indeed become an idea whose time had come.

\section{Institutions in Time: Path Dependence, Reproduction and Evolution}

Understanding the contingency of institutional creation also leads to a better understanding of the downstream effects of such moments as well. The importance of a critical juncture in the creation of the NSC (and the National Security Act) is not just that it provided an opportunity for interested parties to pursue their preferences, but also that that particular moment gave rise to specific options that were otherwise completely off the table. The importance of "historical causes" therefore goes beyond just creating a moment for actors to bargain, but allows for "some historical event or process generate a particular outcome, which is then reproduced through time even though the original generating event or process does not recur" (Pierson 2004: 45). That is to say that the very "stickiness" of institutions is predicated on the critical juncture, not just the particulars of bargaining. As Pierson (2004: 51) further states, "what makes a critical juncture 'critical' is that it triggers a process of positive feedback".

The goal of institutional analysis is often to understand why particular political orders are robust, and difficult to overcome. Choice theoretic approaches to institutions tend to be more interested in the products of institutions, rather than the mechanisms by which they reproduce themselves. As such, the initial choices and unintended consequences of institutional design are often ignored in favor of examining the outcomes. If one real virtue of Zegart's analysis is to move away from such functionalism in order to show how the preferences of actors can lead to sub-optimal institutions, a second is to show that the initial design really matters for the future. She shows in detail, in the example of the NSC, that after the institution had been

\footnotetext{
${ }^{15}$ Another important contingency involved the role of the NSC: the NSC, though argued for by Navy and, to some degree, by President Truman, its exact role and functioning became secondary to the shape of the National Military Establishment, and the role and formal power of the Secretary of Defense. That the NSC would be come a fundamental foreign policy-making body only evolved in time.
} 
inaugurated, its contours remained constant until the present day. Unlike analysts who tended to show that the NSC was shaped more by presidents (and sometimes by national security advisors) (c.f. Daalder and Destler 2009; Rothkopf 2005), Zegart argues that main institutional function stayed constant in time, despite numerous attempts at reform, which is more explained through its creation.

The "stickiness" of initial institutional designs needs to be explained in terms of the mechanisms causing institutional reproduction. The connection between critical junctures and path dependency is here crucial. Critical junctures of events can often lead to courses of action that are difficult to reverse. For path dependency, positive feedback is of central importance, in both showing that costs of changing course will increase over time, and that issues of timing and sequencing are very important (Pierson 2004: 19). As Pierson (2004: 26) states, "in the contexts of complex social interdependence, new institutions often entail high start-up costs, and they produce considerable learning effects, coordination effects and adaptive expectations. Established institutions will typically generate powerful inducements that reinforce their own stability and further development". The robustness of institutions created at critical junctures often relies on positive feedback: that the costs of abandoning such institutions are high, and therefore impede attempts to redesign them.

The path dependent nature of institutions therefore plays an important part in most analyses of institutional design and reproduction (Campbell 2004). Choices made at the outset of institutional design become hard to dislodge overtime because of positive feedback. However, the causal mechanisms of institutional reproduction are often underspecified, and, additionally, underplay the evolution of institutions over time, especially as they cause friction with other extant institutions. Without identifying mechanisms of reproduction, path dependency and positive feedback tends towards a description of stasis, rather than an explanation: what mechanisms lead to reproduction? Thelen (1999) notes two important mechanisms: incentive structure or coordination effects; and distributional effects. In the former, "actors adapt their strategies in ways that reflect but also reinforce the 'logic' of the system" (Thelen 1999: 392). For example, the NSC became a coordinating mechanism despite it being unwanted: but once in place, it was able to deal with coordination problems 
inherent in the fractured nature of foreign policy-making - though the formal system was abandoned rather quickly. Distributional effects point to how institutions inaugurate particular forms of power relations, particularly reinforcing asymmetries in power that can block further change (Thelen 1999; Pierson 2004). In the development of NSC, the manner in which it brought power over foreign policy making into the White House at the expense of other departments in the Executive branch (particularly State), not only reinforced presidential prerogatives in foreign policy, it went along with an overall increasing presidential power in the postwar period (Gould 2003).

As such, the analysis of the reproduction of institutions is as important as the analysis of critical junctures: indeed they go hand in hand. However, a final issue in historical institutional analysis needs to be addressed: the consistent problem with all institutionalist theories has been the desire to explain stability at the price of change (Lieberman 2002; Pierson 2004). Though historical institutionalism has been slightly less susceptible, its focus on path dependence has tended to be more geared towards analyzing radical breaks and stasis, rather than the potential evolution of institutions (Thelen 1999). Pierson has highlighted this by pointing to the limitations in the critical junctures approach in analyzing institutional change: there is no sense of change downstream except for another critical juncture (Pierson 2004). As such historical institutionalism can have too much focus on stability and radical change, too little focus on change over time.

Both Pierson and Thelen have tried to mitigate such problems by pointing to the importance of institutional evolution, to provide another way of looking at institutional development. The main theme of such an approach examines the multiple interactions of institutions, in that institutions always overlap and interact with other institutions. Mechanisms leading to evolutionary change in institutions tend to focus on processes such as layering, functional conversion, and diffusion (Pierson 2004: 137). Moving away from institutional creation and stasis (or stasis punctuated by radical change) points to a key insight of recent historical institutionalist work: the need to better integrate and understand processes of change and stability. As Pierson (2004: 166) states, "if institutional development is understood as an unfolding historical process, it is simply a mistake to juxtapose theories of 
institutional stability and theories of institutional change. One cannot have one without the other".

\section{The Evolution and Reproduction of the National Security Council}

Amongst a number of other agencies, ${ }^{16}$ the National Security Act of 1947 created a Cabinet level Secretary of Defense and the National Military Establishment; the Joint Chiefs of Staff; the National Security Council; and the Central Intelligence Agency. It is important to point out the continued change over time: the defence establishment continued to react and be shaped by external events, but merely as amendments to the Act. However, the importance of the new security bureaucracies was seen in their quick evolution. From the initial National Security Act, between 1949 and 1953, changes were made that impacted on the solidification of the bureaucracy: the creation of an executive-level Department of Defense; the abolition of the Cabinet positions of the Army, Navy and Air Force, along with their seats on the NSC (these first two changes being part of the 1949 amendments to the National Security Act), and the creation of the position of special Assistant to the President for National Security Affairs (aka National Security Advisor). All in all, the quick institutional evolution and reproduction is a hugely important part of the analysis of these institutions. The NSC itself evolved quite quickly from its proposed formal role in the national security apparatus, and after which was rather stable in reproducing itself. How can we understand institutional reproduction and evolution in the case of the NSC? There are really two important processes that need to be better accounted for: the evolution of the NSC from an under-used formal coordination body into the centre of presidential-led national security; and the feedback mechanisms that made changes from the institutional path so hard to dislodge.

In terms of evolutionary mechanisms, the clearest explanation is in terms of functional conversion, that the formal NSC gave way in a period of about ten years to the "informal" focus on the NSC staff, and the National Security Advisor as a key policy aide (or even policy advocate). As Pierson (2004: 138) argues, "because the meaning of formal rules must be interpreted, and multiple interpretations are often plausible, the substantive role of a set of

\footnotetext{
${ }^{16}$ Including three separate armed services - the Departments of Army, Navy and Air Force - the National Security Resources Board, the Munitions Board, the War Council, and the Research and Development Board.
} 
rules may change even in the absence of formal revision". What is important for the first stage of change is in terms of a redefinition of the purpose and function of the NSC, while still working within the formal written rules.

The NSC is now at the heart of the transformation of security thinking, and is also the institution that not only put security policy-making squarely in the White House, but also served the purpose of effectively fusing civilian and military functions, as much as the creation of the Department of Defense. As James Forrestal described it, the NSC would provide for "the formal coordination between the formulators of foreign policy and the formulators of military policy [and] prevent us from coming from face to face with war for which we are unwarned or militarily unprepared" (cited in Caraley 1966: 161). Overall, the NSC system provided a major change in civil-military relations. The crucial change was to have civilian management of the security system: no more direct access to the president by the military departments, a civilian manager in charge of the military organization and budget, and civilian advisors leading security policy.

However, the NSC itself only began to play this role by the 1960s as presidents realized its value in centering foreign policy within the White House. Although Truman and Eisenhower did not have the informal White House-centered foreign policy systems that characterized later administrations, they moved towards inflating informal roles such as that of staff secretaries and special advisors, while still promoting, to some extent, the formal NSC. However, in the early years, the NSC system was not used for much more than information, and was not used extensively by President Truman. This was partly to do with its novelty and lack of familiarity, but also to do with the way it was organized: it was more oriented towards giving policy papers on very specific international issues, a service led by the Policy Planning Staff (PPS) of the Department of State (Nelson 1981: 237-238). ${ }^{17}$ A major shift occurred at the end of the 1940s, mainly through the departure of George Kennan from the PPS, which allowed the NSC to have a mandate towards long-term strategic planning, which had been long-desired by the Defense establishment, and a mandate which

\footnotetext{
${ }^{17}$ Particular influence in the type of information provided was given by Secretary of State Dean Acheson and Policy Planning Staff director George Kennan.
} 
Secretary Acheson also favored (Nelson 1981: 241). The move to long-term planning was emphasized in the creation of one of the founding documents of Cold War national security policy, NSC-68, which was delivered in April, 1950 (May 1993).

Analyses of Eisenhower's use of the NSC often focus on its formality: the council conducted regular meetings, in an attempt to re-establish the Council as the principal forum for establishing security policy, which Eisenhower saw as the original purpose behind its creation (Falk 2004: 41). The traditional focus on the formality of the Eisenhower system often misses the underlying informality which rather reflected things to come. Despite the presence of formality, especially in terms of respecting the inter-departmental cooperation that the NSC was supposed to foster, much foreign policy-making was done through the advice of trusted advisors, such as Secretary of State Dulles, and Eisenhower's staff secretary Andrew J. Goodpaster (Destler 1986). In fact it has been noted that Goodpaster acted more like future national security advisors, and set a precedent for the Kennedy Administration (Destler 1981: 267; Zegart 1999: 82-83).

The NSC system had become predominately under the president's control by the time of the Kennedy Administration. If Eisenhower had done much to institutionalize the formal, statutory NSC system, Kennedy pushed it from being a mere advisory body to an important policy-creation institution, which was geared towards serving the president's interests in foreign policy. This is exemplified in both the merging of the national security advisor and staff secretary into one role. Additionally, the NSC staff became much more presidential in its orientation. Originally conceived of as being non-partisan, to then being at least an interDepartmental working group, the staff, led by the national security advisor, became the president's foreign policy team. The real move was away from the formal, statutory institution of the NSC towards its staff. As Zegart (1999: 76) argues, "by 1963, the organization ... had become a shadow body, legitimating decisions that were debated and decided elsewhere". Overall, the NSC system evolved into less of an inter-Departmental information source than as a policy implementer (Destler 1981). The key initial evolution was the functional conversion of the NSC from a formal institution mainly used to provide a 
forum for key cabinet members of the foreign policy team to a more informal focus on the NSC staff that worked for the president.

Such an evolution went hand in hand with the strengthening of the NSC-led coordinating role, through both a distributional mechanism, which saw an increase in presidential power in foreign policy through the use of the NSC, and a coordinating mechanism, which saw the actors involved with the NSC system play by its rules. The development of substantial political authority increased the asymmetry of relations in the development of security institutions, reflecting an overall increase of power in the White House. As Daalder and Destler (2009: 7) note, "since then, presidents have given less priority to making the overall government function with maximum effectiveness, and more to having a White House staff that is loyal to them alone". Talk of an "imperial presidency" in the 1960s reflected this (e.g. Schlesinger 1973). In the security sphere, such imbalances are still felt today (e.g. Savage 2007). The institutionalization of authority also leads to positive feedback.

The change in the balance of power can be seen in the practice of NSC staff under Kennedy and Nixon, where National Security Advisors McGeorge Bundy and Henry Kissinger eclipsed the Secretaries of State, ${ }^{18}$ and the NSC staff became much more vocal about advocating specific policy positions, rather than being a non-partisan information source; in essence they became the president's advisors instead of professional bureaucrats (Zegart 1999: 84). As Destler (1981: 268) points out, in the Kennedy administration, "particular members of the staff, like [Robert] Komer and Bundy's deputy Carl Kaysen, did become identified with strong policy preferences that they worked to advance" (c.f. Daalder and Destler 2009: esp. chap. 2). The way in which Kissinger dominated foreign policy during the Nixon administration is well-known (e.g. Hanhimäki 2004), and from the outset, Kissinger sought to re-assert the centrality of the NSC by re-establishing the formality seen in the Eisenhower administration, but by also retaining the informality of the Kennedy and Johnson administrations. ${ }^{19}$ Overall, as Destler (1981: 271) states, "in the process of

\footnotetext{
${ }^{18}$ In Kissinger's case, he filled both posts at once after 1973.

19 "National Security Decision Memorandum 2", distributed on January 20, 1969 to key foreign policy elites, outlines the renewed focus on the NSC quite clearly. See U.S. Department of State (2006: 30-33).
} 
developing and dominating these procedures, Kissinger made many specific policy decisions himself'.

President Reagan wanted to make the NSC less visible, and put it back to its intended role, after both the dominance of Kissinger and the very public divisions between Cyrus Vance and Zbignew Brzezinski during the Carter administration. However, there were already difficulties three weeks into his administration, found in a public dispute between his Secretary of State and White House aides. As Destler (1981: 264) points out, "that dispute raised serious questions about whether the president and his chief advisors could resist the broader forces that had brought the White House staff to foreign policy prominence and sometimes dominance”. Additionally, and most prominently, the Iran-Contra scandal again pointed to the problems of the quasi-autonomy of the NSC to implement national security policy (Daalder and Destler 2009: chap. 5; Rothkopf 2005: chap. 8). Iran-Contra not only pointed to the problems that could occur when the NSC was given too much autonomy, but also indicated how central to the policy process it had become. As Lou Cannon noted, "Reagan's national security advisers wielded insufficient influence and excessive power" (cited in Daalder and Destler 2009: 154): while different management styles and personalities could impact how the system played out, there was no moving away from the White Housedominated power dynamics.

Overall, once the NSC had evolved into the more informal, staff-centered version, the mechanisms that reproduced it were further reinforced. Following the rules became crucial early on, as the NSC was at the centre of coordinating the increasingly massive security bureaucracy. Additionally, because of the rise in importance of the security bureaucracy, interests were reformulated in ways that coincided with the NSC-led security system: the NSC allowed for further power for the president over foreign policy that was never going to be easily given up. The informalization process led to an increase in presidential power over foreign policy that echoed the overall increase in presidential power over the course of the twentieth century (Gould 2003). The power asymmetries that the NSC gave the president were rather substantial, mainly to do with the rather insulated nature of the NSC: it was part of the Office of the President, had little to no Congressional oversight (e.g. the National 
Security Advisor did not have to be confirmed by Congress), and had pretty much unlimited access to intelligence. The pre-World War II "security" policy-making was much more coordinated between various executive departments, where such departments were meant to have degrees of autonomy from the White House. As such, the NSC system as it existed by about the mid-1960s became the centre of foreign and defence policy making, and was almost impossible to dislodge, despite a number of scandals (e.g. Iran-Contra), perceived abuses of power, and reform proposals. ${ }^{20}$ After an initial evolutionary period, where the new institution of the NSC was bedded in, the increasing necessity of playing by its rules (coordination effects), and the increasing power asymmetries that it created (distributional effects) allowed for the reproduction of this core security institution over time.

\section{Conclusion}

The preceding analysis of the development of the NSC in the context of the 1947 National Security Act in the US demonstrates the benefits of a historical institutionalist analysis in IR. It is not necessarily meant to show that historical institutionalism provides the best theory, but to demonstrate its effectiveness in providing better explanations of the creation of and reproduction of institutions in time, the importance of causal mechanisms in accounts of causation, explanations that are generalizable but contingent on historical context and timing. Historical institutionalism is also valuable as an approach to history that moves beyond description and narration towards explicit causal explanation.

The article also made some modest inroads towards a historical explanation of the development of security institutions in the US postwar, focusing on the NSC. What is crucial about the postwar moment in American political development is not just a focus on methods: it was a profound moment in American state-building, and the institutions of foreign and defence policy have had lasting impressions not only on US foreign policy, but of the organization and character of government overall. The downstream effects of initial choices have been quite large in terms of the size of the state, the proportion of government devoted

\footnotetext{
${ }^{20}$ Destler (1972) notes that numerous reports that were made between World War II and the writing of his 1972 book had mainly been unsuccessful in implementing reform: 7 of the 11 reports had recommended for new mechanisms to place foreign policy squarely in State; two urged alternate solutions; the Jackson report explicitly warned against the concentration of FP decisions in a White House "super staff".
} 
to defence and security, and through institutional isomorphism (May 1992). The overarching historical thesis is that the postwar moment provides a key example of the interface between the "foreign" and "domestic", confounding insular positions in both IR and political science. As such, the postwar moment should be seen as part of a broader debate about the interactions of war and society, and particularly of war and state-building (c.f. Grossman 2002).

Third, the analysis is meant to provide the basis for a comparative approach to examining the development and reproduction of security institutions within states. Such comparisons could be achieved in a number of fruitful ways. One would be in terms of examining the differential impacts of the post-World War II moment on ideas and institutionalization of "national security". For example, examining the development of "national security" within the UK and Canada postwar would provide an interesting comparison to the US case: did the impact of war in these instances have similar long-term effects in developing national security institutions? A second approach would provide comparison within the US context, looking at other decisive moments of the transformation of security institutions within the US. A core example would be the 1986 Goldwater-Nichols Act, which fundamentally transformed the organization of the armed forces (Locher 2003): what events precipitated this transformation; how did it interact with existing institutions; and in what ways has the reformed system reproduced itself since? The point of historical institutionalism as a mode of analysis is that in these different historical and institutional contexts outcomes will likely differ, thus highlighting the importance of a conjunctural analysis, rather than attempting to provide a general theory of institutional creation and reproduction.

Finally, the development of a national security state, in terms of its historicity, and especially mechanisms of reproduction and evolution, has important impacts on the analysis of present US foreign policy. The national security state has significant contemporary resonances that need to be better explained. For example, a historical explanation can better account for why change was possible in 1947 and why changes in the institutions of national security have been so difficult since, despite increasing concerns about militarism and civilmilitary relations (e.g. Bacevich 2006). Overall, the article demonstrates the benefits of a 
historical institutionalist reading of the postwar moment, both in terms of an approach to domestic institutional creation, and the enduring legacies that are revealed.

\section{References}

Abbott, Andrew. (2001) On the Concept of Turning Point. In Time Matters: On Theory and Method, Chicago: University of Chicago Press.

Allison, Graham and Philip Zelikow. (1999) Essence of Decision: Explaining the Cuban Missile Crisis. $2^{\text {nd }}$ ed. London: Pearson.

Bacevich, Andrew. (2006) The New American Militarism. New York: Oxford University Press.

Bensel, Richard. (1990) Yankee Leviathan: The Origins of Central State Authority in America, 1859-1877. Cambridge: Cambridge University Press.

Borklund, C. W. (1968) The Department of Defense. London: Praeger.

Brinkley, Alan. (1996) The End of Reform: New Deal Liberalism in Recession and War. New York: Vintage Books.

Campbell, John. (2004) Institutional Change and Globalization. Princeton: Princeton University Press.

Capoccia, Giovanni, and R. Daniel. Kelemen. (2007) The Study of Critical Junctures: Theory, Narrative, and Counterfactuals in Historical Institutionalism. World Politics 59(3): 341-369.

Caraley, Demetrios. (1966) The Politics Of Military Unification: A Study of Conflict and the Policy Process. New York: Columbia University Press.

Carlsnaes, Walter. (2002) Foreign Policy. In Handbook of International Relations, edited by Walter Carlsnaes, Thomas Risse and Beth A. Simmons. London: Sage.

Daalder, Ivo B. and I. M. Destler. (2009) In the Shadow of the Oval Office. New York: Simon and Schuster.

Destler, I. M. (1981) National Security II: The Rise of the Assistant (1961-1981). In The Illusion of Presidential Government, edited by Hugh Heclo and Lester M. Salamon. Boulder, CO: Westview Press.

Destler, I. M. (1986) The Presidency and National Security Organization. In The National Security: Its Theory and Practice, 1945-1960, edited by Norman A. Graebner. New York: Oxford University Press.

Destler, I. M. (1972) Presidents, Bureaucrats, and Foreign Policy: The Politics of Organizational Reform. Princeton: Princeton University Press. 
Falk, Stanley L. (2004) The National Security Council under Truman, Eisenhower and Kennedy. In Fateful Decisions: Inside the National Security Council, edited by Karl F. Inderfurth and Loch K. Johnson. New York: Oxford University Press.

Fearon, James and Alexander Wendt. (2001) Rationalism v. Constructivism: A Sceptical View. In Handbook of International Relations, edited by Walter Carlsnaes, Thomas Risse and Beth A. Simmons. London: Sage.

Friedberg, Aaron L. (2000) In the Shadow of the Garrison State: America's Antistatism and its Cold War Grand Strategy. Princeton: Princeton University Press.

Gaddis, John Lewis. (1987) The Insecurities of Victory: The United States and the Perception of Soviet Threat After World War II. In The Long Peace. Oxford: Oxford University Press.

Gaddis, John Lewis. (2004) Surprise, Security, and the American Experience. London: Harvard University Press.

Garrison, Jean A. (ed) (2003) Foreign Policy Analysis in 20/20: A Symposium. International Studies Review 5(2): 155-202.

Glenn, Brian J. (2004) The Two Schools of American Political Development. Political Studies Review 2(2): 153-165.

Gould, Lewis L. (2003) The Modern American Presidency. Lawrence: University Press of Kansas.

Grossman, Andrew D. (2001) Neither Dead nor Red: Civil Defense and American Political Development during the Early Cold War. New York: Routledge.

Grossman, Andrew D. (2002) The Early Cold War and American Political Development: Reflections on Recent Research. International Journal of Politics, Culture and Society 15(3): 471-483.

Hall, Peter and Rosemary Taylor. (1996) Political Science and the Three New Institutionalisms. Political Studies 44(5): 936-957.

Hammond, Paul Y. (1977) Organizing for Defense: The American Military Establishment in the Twentieth Century. Westport, CT: Greenwood Publishing.

Hanhimäki, Jussi. (2004) The Flawed Architect: Henry Kissinger and American Foreign Policy. Oxford: Oxford University Press.

Hay, Colin. (1999) Crisis and the Structural Transformation of the State: Interrogating the Process of Change. British Journal of Politics and International Relations 1(3): 317-344.

Heale, M. J. (1990) American Anti-Communism: Combating the Enemy Within, 1830-1970. Baltimore, MD: Johns Hopkins University Press.

Hill, Christopher. (2003) The Changing Politics of Foreign Policy. Basingstoke: Palgrave. 
Hogan, Michael J. (1998) A Cross of Iron: Harry S. Truman and the Origins of the National Security State 1945-1954. Cambridge: Cambridge University Press.

Hudson, Valerie M. (2005) Foreign Policy Analysis: Actor Specific Theory and the Ground of International Relations. Foreign Policy Analysis 1(1): 1-30.

Ikenberry, G. John. (2001) After Victory: Institutions, Strategic Restraint, and the Rebuilding of Order After Major Wars. Princeton: Princeton University Press.

Immergut, Ellen M. (1998) The Theoretical Core of the New Institutionalism. Politics and Society 26(5): 5-34.

Kennan, George [X]. (1947) The Sources of Soviet Conduct. Foreign Affairs 25(July): 566582.

Koistinen, Paul A.C. (2004) Arsenal of World War II: The Political Economy of American Warfare, 1940-1945. Lawrence: University Press of Kansas.

Krasner, Stephen D. (1984) Approaches to the State: Alternative Conceptions and Historical Dynamics. Comparative Politics 16(2): 223-246.

Krasner, Stephen D. (ed) (1981) International Regimes. Ithaca: Cornell University Press.

Kratochwil, Friedrich and John Gerard Ruggie. (1986) International Organization: A State of the Art on an Art of the State. International Organization 40(4): 753-775.

Lasswell, Harold. (1941) The Garrison State. American Journal of Sociology 46(January): 455-468.

Leffler, Melvyn. (1984) The American Conception of National Security and the Beginnings of the Cold War. American Historical Review 89(2): 346-381.

Lieberman, Robert C. (2002) Ideas, Institutions, and Political Order: Explaining Political Change. American Political Science Review 96(4): 697-712.

Locher, James R. (2002) Victory on the Potomac: The Goldwater-Nichols Act Unifies the Pentagon. College Station: Texas A \& M University Press.

Mahoney, James. (2000) Path Dependence in Historical Sociology. Theory and Society 29(4): 507-548.

Mahoney, James and Dietrich Rueschemeyer. (2003) Comparative Historical Analysis: Achievements and Agendas. In Comparative Historical Analysis in the Social Sciences, edited by James Mahoney and Dietrich Rueschemeyer. Cambridge: Cambridge University Press.

March, James G. and Johan P. Olsen. (1984) The New Institutionalism: Organizational Factors in Political Life. American Political Science Review 78(3): 734-749.

Matthews, Geoffrey. (1982) Robert A. Taft, The Constitution and American Foreign Policy, 1939-53. Journal of Contemporary History 17(3): 507-522. 
May, Ernest R. (1955) The Development of Political-Military Consultation in the United States. Political Science Quarterly LXX(2): 161-180.

May, Ernest R. (1992) The U.S. Government, a Legacy of the Cold War. In The End of the Cold War: Its Meanings and Implications, edited by Michael J. Hogan. Cambridge: Cambridge University Press.

May, Ernest R. (ed) (1993) American Cold War Strategy: Interpreting NSC 68. New York: Bedford/St. Martin's, 1993.

Mayhew, David R. (2005) Wars and American Politics. Perspectives on Politics 3(3): 473493.

Moe, Terry. (1984) The New Economics of Organization. American Journal of Political Science 28(4): 739-777.

Nelson, Anna Kasten. (1981) National Security I: Inventing a Process (1945-1960). In The Illusion of Presidential Government, edited by Hugh Heclo and Lester M. Salamon. Boulder: Westview Press.

Neu, Charles E. (1987) The Rise of the National Security Bureaucracy. In The New American State, edited by Louis Galambos. Baltimore: Johns Hopkins University Press.

Nexon, Daniel H. (2009) The Struggle for Power in Early Modern Europe. Princeton: Princeton University Press.

Pierson, Paul. (2000) Not Just What, but When: Issues of Timing and Sequencing in Political Processes. Studies of American Political Development 14(1): 72-92.

Pierson, Paul. (2004) Politics in Time: History, Institutions, and Social Analysis. Princeton: Princeton University Press.

Porter, Bruce D. (1994) War and the Rise of the State: The Military Foundations of Modern Politics. New York: Free Press.

Prados, John. (1991) Keepers of the Keys: A History of the National Security Council from Truman to Bush. New York: Morrow.

Prange, Gordon V., with Donald M. Goldstein and Katherine V. Dillon. (1991) At Dawn we Slept: The Untold Story of Pearl Harbor. New York: Penguin Books.

Rothkopf, David. (2005) Running The World: the Inside Story of the National Security Council and the Architects of American Power. New York: Public Affairs.

Savage, Charlie. (2007) Takeover: The Return of the Imperial Presidency and the Subversion of American Democracy. New York: Little, Brown and Company.

Sewell, William H. (2005) Three Temporalities: Towards an Eventful Sociology. In Logics of History: Social Theory and Social Transformation. Chicago: University of Chicago Press.

Schlesinger, Arthur M., Jr. (1973) The Imperial Presidency. Boston: Houghton Mifflin Company. 
Shaw, Martin. (1988) Dialectics of War. London: Pluto.

Sherry, Michael S. (1997) In the Shadow of War: America since the 1930s. New Haven: Yale University Press.

Skowronek, Stephen. (1982) Building a New American State: The Expansion of National Administrative Capacities. Cambridge: Cambridge University Press.

Spruyt, Hendrik. (1994) The Sovereign State and Its Competitors: An Analysis of Systems Change. Princeton: Princeton University Press.

Stuart, Douglas T. (2008a) Creating the National Security State. Princeton: Princeton University Press.

Stuart, Douglas T. (2008b) Constructing the Iron Cage: The 1947 National Security Act. In Affairs of State: The Interagency and National Security, edited by Gabriel Marcella. Carlisle, PA: U.S. Army Strategic Studies Institute.

Thelen, Kathleen. (1999) Historical Institutionalism and Comparative Politics. Annual Review of Political Science 2: 369-404.

Tilly, Charles. (1995) To Explain Political Processes. American Journal of Sociology 100 (6): 1594-1610.

Truman, Harry S. (1947) 'Special Message to the Congress on Greece and Turkey: The Truman Doctrine', March 12, 1947. In The American Presidency Project [online], edited by John T. Woolley and Gerhard Peters. Santa Barbara, CA. $<$ http://www.presidency.ucsb.edu/ws/?pid=12846> 13 July 2010.

Truman, Harry S. (1956) Memoirs, Vol. 2: Years of Trial and Hope. Garden City, NY: Doubleday.

U.S. Department of State. (2006) Foreign Relations of the United States, 1969-1976: Volume II, Organization and Management of U.S. Foreign Policy, 1969-1972. Washington, DC: GPO.

Waddell, Brian. (2001) The War Against the New Deal: World War II and American Democracy. DeKalb: Southern Illinois University Press.

Wendt, Alexander. (2001) Driving with the Rearview Mirror: On the Rational Science of Institutional Design. International Organization 55(4): 1019-1049.

Wohlstetter, Roberta. (1962) Pearl Harbor: Warning and Decision. Stanford: Stanford University Press.

Yergin, Daniel. (1977) Shattered Peace: The Origins of the Cold War and the National Security State. Boston: Houghton Mifflin.

Zegart, Amy. (1999) Flawed by Design: The Evolution of the CIA, JCS, and NSC. Stanford: Stanford University Press. 